\title{
Patterns of variability of retinol levels in a harbour porpoise population from an unpolluted environment
}

\author{
Asunción Borrell ${ }^{1, *}$, Gemma Cantos ${ }^{1}$, Alex Aguilar ${ }^{1}$, Christina Lockyer ${ }^{2}$, \\ Abraham Brouwer ${ }^{3}$, Mads Peter Heide-Jørgensen ${ }^{4}$, Jette Jensen ${ }^{5}$, Bert Spenkelink ${ }^{3}$ \\ ${ }^{1}$ Dept of Animal Biology, Faculty of Biology, University of Barcelona, E-08071 Barcelona, Spain \\ ${ }^{2}$ Dept of Marine Fisheries, Danish Institute for Fisheries Research, DK-2920 Charlottenlund Slot, Denmark \\ ${ }^{3}$ Dept of Food Technology and Nutritional Sciencies, Division of Toxicology, Agricultural University, \\ 6703 HE Wageningen, The Netherlands \\ ${ }^{4}$ Greenland Institute of Natural Resources, NERI, DK-2200 Copenhagen, Denmark \\ ${ }^{5}$ ASCOBANS Secretariat, C/o Sea Mammal Research Unit, Cambridge CB3 0ET, United Kingdom
}

\begin{abstract}
Organochlorine compounds (OC) are known to induce vitamin A. (retinoids) deficiency in mammals, which may be associated with impairment of immunocompetence, reproduction and growth. This makes retinoids a potentially useful biomarker of organochlorine impact on marine mammals. However, use of retinoids as a biomarker requires knowledge about its intrapopulation patterns of variatjon in natural conditions, information which is not currently available. We investigated these patterns in a cetacean population living in an unpolluted environment. 100 harbour porpoises Phocoena phocoena from West Greenland were sampled during the 1995 hunting season. Sex, age, morphometrics, nutritive condition, and retinol (following saponification) and $O C$ levels in blubber were determined for each individual. OC levels found were extremely low and therefore considered unlikely to affect the population adversely: mean blubber concentrations, expressed on an extractable basis, were 2.04 ( $\mathrm{SD}=$ 1.1) $\mathrm{ppm}$ for PCBs and $2.76(\mathrm{SD}=1.66) \mathrm{ppm}$ for $\mathrm{tDDT}$. The mean blubber retinol concentration for the overall population was $59.66(\mathrm{SD}=45.26) \mathrm{\mu g} \mathrm{g}^{-1}$ Taking into account the high contribution of blubber to body mass, blubber constitutes a significant body site for retinoid deposition in harbour porpoises. Retinol concentrations did not differ significantly between geographical regions or sexes, but they did correlate significantly $(p<0.001)$ with age. Body condition, measured by determining the lipid content of the blubber, did not have a significant effect on retinol levels but the individuals examined were considered to be in an overall good nutritive condition. It is concluded that measurement of retinol concentrations in blubber samples is feasible and has a potential for use as a biomarker of organochlorine exposure in cetaceans. However, in order to do so, biological information, particularly age, is critical for the correct assessment of physiological impact.
\end{abstract}

KEY WORDS: Harbor porpoise - Retinol - Organochlorines B Biomarker - Greenland

\section{INTRODUCTION}

A central, yet unresolved issue in ecotoxicology is the relationship between cause and effect of pollutant concentrations in organisms. In recent years, such relationships have usually been assessed using biomark-

\footnotetext{
·E-mail: assump@porthos.bio.ub.es
}

ers, which are xenobiotically induced variations that reflect the physiological impact of pollutants (NRC 1987).

Among the vertebrates, odontocete cetaceans are those in which the highest concentrations of organochlorines (OC) have been found $\left(\mathrm{O}^{\prime}\right.$ Shea \& Aguilar in press). However, the actual impact of these pollutants and their pathways of action in odontocetes have yet to be determined although, given their similarity to other 
mammals, the adverse effects of these pollutants on reproduction and immunocompetence have been repeatedly suggested.

In vertebrates, organochlorines are known to induce vitamin A-depletions. These effects have been demonstrated experimentally and in the wild (Peakall 1992, Spear et al. 1992, Swart et al. 1994, Morse \& Brouwer 1995). Retinoids are a group of lipid soluble substances that possess a vitamin A-like biological activity (Wolf 1984). In mammals, retinoids are essential nutrients (i.e. they must be provided in the diet) and are fundamental for growth, vision, reproduction, epithelial differentiation and immune function. Retinoid concentrations tend to reflect vitamin A availability in the diet and, thus, are high in marine species that feed on marine fish rich in retinoid and carotenoids.

The liver is the main, though not exclusive, storage site for retinoids. Other retinoid storage sites are kidneys, depot fat, lungs and adrenal glands (Blomhoff et al. 1991). However, most retinol determinations in marine mammals have been made in the liver and plasma, tissues which require the handling of the individual or its necropsy. In some instances, though restricted to pinnipeds, hypodermic fat has also been analysed (Rodahl \& Davis 1949, Schweigertet al. 1987, Schweigert \& Buchholz 1995, Käkelä et al. 1997). The use of hypodermic fat has the advantage that freeranging individuals can be sampled at a distance using biopsy darts, a technique which is comparatively less invasive than the methods commonly required for sampling other tissues.

The combination of blubber biopsy techniques (Aguilar \& Borrell 1994) with the subsequent analysis of the tissue offers the possibility of using retinol as a biomarker of organochlorine pollutants in free-ranging odontocete cetaceans in the wild. However, this requires baseline data on the range of concentrations of

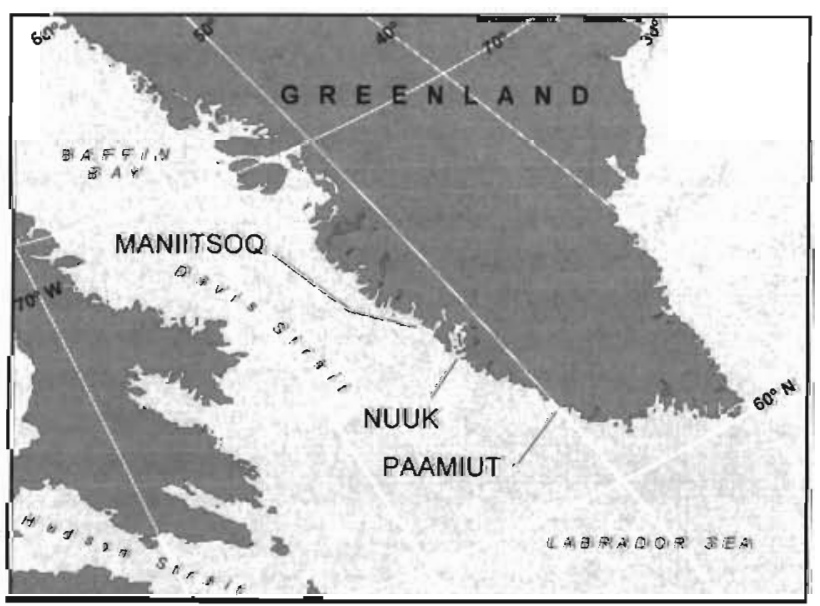

Fig. 1. Localities where the harbour porpoises were collected retinol in natural conditions, that is, in populations which are not affected by exposure to pollutants.

The present study aims at filling this gap. Its objective is to establish intrapopulation patterns of retinol concentrations in the blubber of harbour porpoises from Greenland, an environment which remains comparatively unaffected by pollutants. Thus, we investigated differences in retinol concentrations between sampling locations as well as those associated with age, body length, sex and body condition. It is expected that these data will provide the basis for the use of retinol as a biomarker for the species.

\section{MATERIAL AND METHODS}

We examined and sampled 100 harbour porpoises (54 females and 46 males) caught during the 1995 hunting season in 3 different regions of West Greenland: Maniitsoq $(\mathrm{n}=51)$, Nuuk $(\mathrm{n}=36)$ and Paamiut $(\mathrm{n}=13)$ (Fig. 1). Porpoises were measured, weighed and sexed, and teeth from the lower jaw and a sample. of blubber from the central dorsal region of the trunk collected. This blubber sample was used for the analyses of lipid content, organochlorine concentration and retinol levels.

Age determination. The teeth were cleaned (but not boiled) and fixed in 10\% neutral buffered formalin. In the laboratory they were decalcified in Rapid Bone Decalcifier for the Preparation of Histological Materials (RDO), a commercially prepared mixture of acids, for 2 to $8 \mathrm{~h}$ depending on tooth volume. Teeth were then longitudinally sectioned in a freezing microtome, stained with hematoxylin, blued in weak ammonia solution, and mounted onto gelatin-coated slides. Age was determined by counting growth layer groups (GLG) in dentine, assuming that each GLG corresponded to $1 \mathrm{yr}$. More detail on the techniques used can be found in Lockyer $(1995 a, b)$.

Nutritive condition. The nutritive condition of the individuals was assessed by examining the lipid content of a blubber sample weighing about $3 \mathrm{~g}$. This was determined gravimetrically from the lipid extract obtained from the Soxhlet extraction made for the OC analysis (see below). Lipid content was expressed as a percentage of blubber wet weight (blubber lipid content, BLC\%). Blubber lipid richness is considered a sensitive indicator of cetacean condition (e.g. Aguilar \& Borrell 1990, Lockyer 1995c).

Blubber organochlorine pollutant concentrations. The blubber samples were preserved in deep freeze $\left(-20^{\circ} \mathrm{C}\right)$ awaiting analysis. Once in the laboratory, samples weighing about $3 \mathrm{~g}$ were ground with anhydrous sodium sulfate and extracted with $\mathrm{n}$-hexane (residuefree quality) in a Soxhlet apparatus for $5 \mathrm{~h}$. The solu- 
tion obtained was concentrated to $40 \mathrm{ml}$. A portion of this extract $(10 \mathrm{ml})$ was used to determine the quantity of extractable fat $\mathrm{g}^{-1}$ of blubber. A further quantity was mixed with sulfuric acid for the clean up, following the procedures described by Murphy (1972), and the resulting extract was concentrated to $1 \mathrm{ml}$ and centrifuged for $5 \mathrm{~min}$

Chromatographic analysis was carried out on a Hewlett-Packard 5890-II G.C., equipped with an electron capture detector (ECD) at $350^{\circ} \mathrm{C}$. A fused silica capillary column (length $60 \mathrm{~m}, 0.25 \mathrm{~mm}$ internal diameter, i.d.) coated with SPB-1 was used as the stationary phase $(0.25 \mu \mathrm{m}$ film thickness). The splitless technique was used to inject $1 \mu l$ of the purified extract. Pure nitrogen at a flow rate of $1 \mathrm{ml} \mathrm{min}^{-1}$ was used as a carrier gas. Temperature was programmed as follows: injection at $40^{\circ} \mathrm{C}$ for $1 \mathrm{~min}$ and increased to $170^{\circ} \mathrm{C}$ at a rate of $25^{\circ} \mathrm{C} \mathrm{min}^{-1} ; 1$ min constant to $250^{\circ} \mathrm{C}$ at a rate of $2^{\circ} \mathrm{C}$ min $^{-1}$ and then to $280^{\circ} \mathrm{C}$, at $5^{\circ} \mathrm{C} \mathrm{min}^{-1}$.

A preliminary screening of the samples revealed that heptachlor was not present in the tissues analysed. Therefore, this compound $\left(0.1 \mu \mathrm{g} \mathrm{g}^{-1}\right)$ was used as an internal standard.

The samples were analyzed for the following compounds: HCB, p, $p^{\prime}$-DDE, p, p'-DDD, o, $p^{\prime}$-DDT, p, $p^{\prime}-$ DDT and polychlorinated biphenyls (PCBs). Total PCB concentration (tPCB) was calculated as the sum of 20 individual peaks (IUPAC\# 95, 101, 110+136, 151, $135+144,149,153,141,138,187,183+128,174,177$, $171+202,180,170,201,203+196,195,194) . t D D T$ is the sum of the 4 DDT compounds. Concentrations are expressed in $\mu \mathrm{g} \mathrm{g}^{-1}$ of extracted lipid.

Blanks of pure n-hexane were daily run to ensure the purity of the system. Recoveries of all the organochlorine compounds were calculated by adding known quantities of standard to 12 homogenate replicates of the same sample. They ranged from 82 to $101 \%$.

Blubber retinol concentrations. The blubber samples, weighing about $1 \mathrm{~g}$ each, were homogenised with a Sorvall apparatus. Three subsamples weighing ca $100 \mu \mathrm{g}$ were drawn from each homogenate. Subsamples were saponified overnight in an ethanolic $\mathrm{KOH}$ solution ( $1 \mathrm{~g} \mathrm{KOH}, 2 \mathrm{ml}$ distilled $\mathrm{H}_{2} \mathrm{O}, 2 \mathrm{ml}$ ethanol, $20 \mu \mathrm{g}$ ascorbic acid) in a mechanical shaker under a nitrogen atmosphere. Retinol was extracted by adding $8 \mathrm{ml}$ diethyl ether and shaking for $30 \mathrm{~min}$. After separation from the aqueous phase, internal standard was added and the organic extract was cleaned 3 times with $4 \mathrm{ml}$ of aqueous phosphates buffer ( $\mathrm{pH} 7.4)$. The extract was dried under nitrogen and reconstituted with $1 \mathrm{ml}$ methanol and $0.1 \%$ butylated hydroxy toluene (BHT) as antioxidant. Reconstituted samples were filtered $(0.45 \mu \mathrm{m}$ mesh) and a $40 \mu \mathrm{l}$ subsample automatically injected (Waters 700 Satellite wisp) on a HPLC (Waters 600 E system Controller pump) equipped with a Restek column (Spherisorb ODS2, $4 \mathrm{~cm}$ length, $3 \mu \mathrm{m}$ beds, $0.46 \mathrm{~cm}$ i.d.) and a UV detector (Waters 486 Tuneable absorbance D) set at $326 \mathrm{~nm}$. The retinol was eluted at a flow rate of $1 \mathrm{ml} \mathrm{min}^{-1}$ using a mobile phase of methanol/water ( $90 / 10$ by volume) for $1.5 \mathrm{~min}$ followed by a linear gradient of $0.5 \mathrm{~min}$ to methanol $100 \%$ for $18 \mathrm{~min}$. Retinyl acetate was used as an internal standard for recovery determinations. The recoveries of retinol in the whole extraction and saponification procedures ranged from $82.27 \%$ to $101.9 \%(n=12)$. During the analysis the blubber samples were prepared at room temperature and, when applicable, under red light and the atmosphere of nitrogen.

Statistics. We examined the influence of biological parameters and geographical location on retinol levels. The assumption of normality of samples was checked using a Kolmogorov-Smirnov test and that of homogeneity of variances between sample groups with a Levene test. As a preliminary analysis we carried out a variance analysis of data on biological parameters and organochlorine pollutants between the samples from the different geographical locations separately for each sex. When this indicated that significant differences existed between groups, the Newman-Keuls multiple range test and the Tukey test were applied to the data to identify the sample pairs presenting differences. Then, we performed a 2-factor (sex and geographical location) analysis of variance (ANCOVA) of retinol concentrations in the blubber of the whole sample combined using age and blubber lipid content as covariates. Finally, the relationship between age and retinol concentrations was examined using standard correlation/mean squares regression analysis. All statistical calculations were carried out using the SPSS- $x$ statistical package.

\section{RESULTS}

The hypothesis of homogeneity of variances for the different variables was not rejected in any of the cases and none of the distributions departed significantly from normality. Table 1 details the biological characteristics of the samples from the different geographical locations. The analysis of the variance of variables between groups concluded that the samples were overall comparable with the exception of the group consisting of males from Maniitsoq, which was composed of older individuals than the Nuuk and Paamiut animals, the difference being highly significant $(\mathrm{p}<$ $0.001)$. This difference in age had a moderate effect on the body length and weight distribution of the porpoises from the different regions, but differences were not statistically significant. The mean BLC of the dif- 
Table 1 Phocoena phocoena. Mean and associated standard deviation of the biological variables measured in the harbour porpoises collected from the different localities. BLC: blubber lipid content; ${ }^{*}$ significantly different

\begin{tabular}{|c|c|c|c|c|c|c|c|c|c|c|}
\hline \multirow{2}{*}{ Locality } & \multirow[t]{2}{*}{ Sex } & \multirow[t]{2}{*}{$\mathrm{n}$} & \multicolumn{2}{|c|}{ Age (yr) } & \multicolumn{2}{|c|}{ Length $(\mathrm{cm})$} & \multicolumn{2}{|c|}{ Weight (kg) } & \multicolumn{2}{|c|}{ BLC $(\%)$} \\
\hline & & & Mean & $\mathrm{SD}$ & Mean & SD & Mean & $\mathrm{SD}$ & Mean & $\mathrm{SD}$ \\
\hline \multirow[t]{2}{*}{ Paamiut } & Females & 4 & 1.3 & 1.0 & 114.5 & 16.1 & 31.5 & 9.4 & 85.0 & 2.7 \\
\hline & Males & 9 & 1.8 & 2.0 & 117.7 & 16.6 & 30.9 & 11.7 & 85.8 & 3.2 \\
\hline \multirow[t]{2}{*}{ Nuuk } & Females & 23 & 3.6 & 3.4 & 135.7 & 21.7 & 42.6 & 14.3 & 83.1 & 7.8 \\
\hline & Males & 13 & 2.9 & 3.0 & 125.5 & 16.0 & 35.3 & 10.3 & 83.8 & 3.2 \\
\hline \multirow[t]{2}{*}{ Maniitsoq } & Females & 27 & 2.6 & 2.1 & 128.6 & 19.2 & 37.5 & 14.0 & 84.2 & 4.2 \\
\hline & Males & 24 & $6.0^{\circ}$ & 4.8 & 132.1 & 14.6 & 42.4 & 11.8 & 83.7 & 3.1 \\
\hline
\end{tabular}

Table 2. Phocoena phocoena. Mean and associated standard deviation of the organochlorine compound concentrations found in the blubber of the harbour porpoises collected from the different localities. Concentrations are expressed as $\mu \mathrm{g} \mathrm{g} \mathrm{g}^{-1} \mathrm{calculated}$ on the basis of the lipids extracted; "significantly different

\begin{tabular}{|c|c|c|c|c|c|c|c|c|}
\hline \multirow[t]{2}{*}{ Locality } & \multirow[t]{2}{*}{ Sex } & \multirow[t]{2}{*}{$n$} & \multicolumn{2}{|c|}{$\mathrm{HCB}$} & \multicolumn{2}{|c|}{$\mu C B$} & \multicolumn{2}{|c|}{ tDDT } \\
\hline & & & Mean & SD & Mean & $\mathrm{SD}$ & Mean & $\mathrm{SD}$ \\
\hline \multirow[t]{2}{*}{ Paamiut } & Females & 4 & 0.19 & 0.07 & 1.26 & 0.64 & 1.93 & 1.07 \\
\hline & Males & 9 & 0.24 & 0.10 & 1.63 & 0.53 & 2.06 & 0.47 \\
\hline \multirow[t]{2}{*}{ Nuuk } & Females & 23 & 0.20 & 0.13 & 1.82 & 0.84 & 2.23 & 1.30 \\
\hline & Males & 13 & 0.26 & 0.09 & 2.43 & 1.38 & 3.63 & 2.18 \\
\hline \multirow[t]{2}{*}{ Maniitsoq } & Females & 27 & 0.21 & 0.11 & 1.79 & 0.65 & 2.36 & 1.01 \\
\hline & Males & 24 & 0.19 & 0.08 & $3.13^{\circ}$ & 1.52 & $4.47^{\circ}$ & 1.98 \\
\hline
\end{tabular}

ferent sample groups ranged from 83.1 to $85.8 \%$ (Table 1). These figures are in the range of $\mathrm{BLC}$ values that in other populations are characteristic of individuals which have thick blubber layer and large body fat stores (Lockyer 1995c), for which reason it was concluded that the individuals sampled for the present study were in an overall good nutritive condition.

Table 2 details blubber organochlorine concentrations by region and sex. Concentrations were extremely low and the limited age- or sex-related variation observed, with concentrations in males increasing with age and those of females decreasing, is consistent with patterns previously observed in other marine mammal species (Aguilar et al. 1998). Such age and sex effects account for some variation between geographical areas. Thus, the males from Maniitsoq, which as seen above were significantly older than the rest, had significantly $(p<0.05)$ higher blubber concentrations of PCBs and tDDT than the other sample groups. Also, concentrations in females were consistently lower (although differences were usually non-significant) than in the males of the same localities.

Table 3 details statistics relative to retinol concentrations in the blubber of porpoises by sex, from the different regions. Concentrations ranged from 5 to $216 \mu \mathrm{g}$ $\mathrm{g}^{-1}$, with mean values in the range from ca 30 to $80 \mu \mathrm{g}$ $\mathrm{g}^{-1}$. The 2-factor (sex and geographical location) ANCOVA of retinol concentrations in the blubber of the sample containing all locations resulted in significantly different slopes between sexes therefore precluding statistical comparison. Closer examination of the results showed that such differences were caused by the heterogeneous age composition of the samples (see above), for which reason a subsequent analysis was carried out on a subsample containing only specimens aged 0 to 7 yr to keep samples within comparable age-ranges.

In this subset, the omnibus comparison test did not reject the hypothesis of equality of means between the different groups, therefore indicating that neither geographical location nor sex had an effect on retinol concentrations in the blubber of the porpoises. Similarly, BLCs, indicative of nutritive condition, had no effect on retinol levels. In contrast, blubber retinol content correlated significantly $(p<0001)$ with age both in males and females. Therefore, retinol concentrations from blubber originating from all regions were pooled and regressed against age to assess age-related variation across the lifespan of the sampled individuals (Fig. 2), The regression equation, $\mathrm{R}^{2}$ value, standard error of the slope, SE(s), and standard error of intercept terms, $\mathrm{SE}$ (i.t.), between retinol concentration and age in males and females were as follows: 
Table 3. Phocoena phocoena. Mean, associated standard deviation and ranges of retinol concentrations found in the blubber of the harbour porpoises collected from the different localities. Concentrations are expressed as $\mu \mathrm{g} \mathrm{g}^{-1}$ calculated in relation to the fresh weight of the tissue

\begin{tabular}{|lcrcrrr|}
\hline \multirow{2}{*}{ Locality } & \multirow{2}{*}{ Sex } & $\mathrm{n}$ & \multicolumn{4}{c|}{ Retinol } \\
& & & Mean & SD & Maximum & Minimum \\
\hline \multirow{2}{*}{ Paamiut } & Females & 4 & 32.64 & 24.54 & 63.11 & 11.57 \\
& Males & 9 & 47.66 & 33.81 & 106.40 & 13.18 \\
\multirow{4}{*}{ Nuuk } & Females & 23 & 63.92 & 46.01 & 185.20 & 8.89 \\
& Males & 13 & 78.37 & 66.59 & 216.53 & 17.12 \\
& Females & 27 & 46.01 & 40.27 & 195.33 & 5.68 \\
& Males & 24 & 69.79 & 37.98 & 138.53 & 17.88 \\
\hline
\end{tabular}

cetaceans worldwide and are almost as low as those of the baleen whales in the colder latitudes where pollution levels are extremely low (as reviewed by O'Shea \& Brownell 1994). These tissue concentrations are well below the threshold levels at which effects have been observed in mammals. Therefore, it seems highly unlikely that the organochlorine pollutant levels observed were able to influence retinol levels and the dynamics of the harbour porpoises studied. Given that no other external factor with the

potential to affect retinol has been identified, it is assumed that our results reliably reflect the tissue and patterns of variability that can be expected for freeranging porpoises in unpolluted conditions.

\section{Blubber as a representative tissue for body retinol levels}

The liver is the principal organ for the storage and release of retinoids, which are mostly deposited in the form of retinyl esters and retinol. However, many other tissues, including blood, also contain modest levels of retinoids (Wolf 1994). This has led researchers to use liver (because of its high retinol content) and blood (because sampling does not require the sacrifice of the individual) for the monitoring of body retinol levels in organisms.

Information on retinoids in cetaceans is extremely limited and mostly restricted to the liver. It has long been known that the liver of cetaceans is extremely rich in retinol (Schmidt-Nielsen et al. 1934), and interest in obtaining Vitamin $A$ for commercial purposes led a number of researchers during the first half of the century to investigate retinol concentrations in the livers of large whales (e.g. Klem 1935, Wetlesen 1938, Braekkan 1948, Ishikawa et al. 1948, 1951, Kaneko 1948, Mori \& Saiki 1950, Tawara \& Fukazawa 1950a, b).

Unlike the liver, other cetacean tissues have received little attention. Moiri \& Saiki (1950) reported retinol concentrations in the blubber and intestine of sperm whales, Gregory et al. (1955) in the milk of blue whales, and Rosas \& Lehti (1996) in the milk of Amazon river dolphins. However, sample sizes in all these studies were extremely limited, often to one single individual, and offer no insight into individual or intrapopulation variation.

The virtual absence of information on blubber is surprising given the fact that in cetaceans it can be easily sampled using non-destructive biopsy techniques (Aguilar \& Borrell 1994) and that adipose tissues in

Concentrations of all organochlorine compounds analysed (Table 2) were the lowest ever recorded in a harbour porpoise population (Aguilar \& Borrell 1995). Indeed, they are within the lowest ranges detected in 
general seem to be particularly sensitive to variations in retinoid body loads. For example, Blaner et al. (1994) found that in a group of rats fed on an excess retinol diet, the adipose tissue level of retinoid rose by 1.8 to 3.6 -fold above the control group while plasma retinol levels remained unaffected by the excess.

Our results show that retinol is present in harbour porpoises blubber in measurable quantities, its mean concentration in the different sample groups being in the range 33 to $78 \mu^{-1} g^{-1}$ (Table 3 ). Because of substantial differences between the analytical methods employed in the present survey and those used in other studies, particularly in those carried out in the 1930s, 1940s and 1950s, comparison of absolute retinol concentrations between species is not possible.

Blubber is by far the largest body fat depot in marine mammals and retinol is highly lipophilic. In these animals, blubber is likely to make an important contribution to total body retinol. This has, indeed, been found to be the case in pinnipeds, for which information on the tissue distribution of retinol is comparatively much more abundant. Thus, Schweigert et al. (1987) calculated that in grey seals about $40 \%$ of total body vitamin A reserves were stored in blubber. In cetaceans, blubber usually comprises 20 to $40 \%$ of the body mass while liver only accounts for 1 to $3 \%$ (Bryden 1972). Harbour porpoises have a much thicker blubber layer than most other cetaceans, so the contribution of this tissue to total body mass is usually in the upper range, i.e. 25 to $55 \%$ (Slijper 1958, Rig et al. 1993, Lockyer 1995c). Considering the high retinol levels found in the blubber of harbour porpoises, blubber represents a potentially significant body site for retinol accumulation in this species.

\section{Factors affecting retinol concentrations in blubber}

The chemical constituents of organisms vary in individuals according to such biological characteristics as age, nutritive condition and others (e.g. Geraci et al. 1979). Retinol is no exception and, in humans and other mammals, the individual's biological characteristics strongly influence tissue concentrations (e.g. Raica et al. 1972, Blomhoff et al. 1988, Zaman et al. 1993).

Our results show that in harbour porpoises retinol increases linearly and significantly with age to about the age of $8 \mathrm{yr}$. Thereafter, concentrations continue rising but the rate of increase appears to be slower (Fig. 2). These trends cannot be compared with those from other cetacean species or populations because of the apparent absence of previously published information on this aspect. The only data existing from other marine mammals is restricted to pinnipeds. Positive correlations of retinol with age were found by South- cott et al. (1974) in the liver of female Australian fur seals, by Käkelä et al. (1997) in the blubber and liver of Lake Saimaa ringed seals, and by Schweigert et al. (1987) in the blubber and liver of grey seals from Sable Island. Data from Rodahl \& Davies (1949) also suggest an age-related rise in retinol levels in liver of hooded and harp seals but unfortunately these were not statistically tested. Conversely, Käkelä et al. (1997) did not observe any significant variation with age in the blubber and liver of Spitsbergen and Baltic ringed seals. Therefore, our data seem to be consistent with observed patterns in seals, in which either a non-significant or an increasing trend are found. This pattern, also observed in humans and other mammals, appears to be the result of a decrease in the circulatory clearance of retinol and other lipo-soluble compounds with age in mammals coupled with a higher than necessary intake of retinoids via diet, which leads to a buildup of retinylester concentrations with age (Maiani et al. 1989, Krasinski et al. 1990).

The influence of sex on retinol concentrations is more difficult to interpret. In our study the slopes of the regression lines from the 2 sexes are statistically indistinguishable and, when normalized for the effect of age, no significant differences were found between the blubber retinol concentrations of males and females. However, the few studies that have been conducted on pinnipeds do suggest sex-related variation although this appears to vary between tissues. Schweigert et al. (1987) found that blubber levels of adult male grey seals were significantly (up to 2 times) lower than those of adult females. On the other hand, data from both Rodahl \& Davies (1949) and Schweigert et al. (1987) show that the livers of male hooded, harp and grey seals have considerably higher liver retinol concentrations than those of females of comparable age. The reasons for these variations are unclear.

The effect of body condition on retinol blubber levels is also difficult to assess. While our results from Greenland harbour porpoises are consistent with those obtained by Rodahl \& Davies (1949) from hooded and harp seals in indicating that condition has no significant effect on retinol levels, this conclusion should be viewed with caution. Retinol is incorporated into the organism via food and its dynamics and body distribution are greatly dominated by its lipophilicity. Both our sample and that described by Rodahl \& Davies (1949) are composed of overall healthy and apparently wellnourished individuals. While in these conditions retinol tissue distribution may remain unaltered, it is highly likely that in situations of food shortage, massive fat mobilisation (e.g. during migration in large baleen whales), or starvation caused by disease or another condition, retinol may be mobilised from blubber together with other fatty components and be redis- 
tributed between tissues or excreted. This effect may be particularly significant if stranded cetaceans, often found in poor nutritive condition, are used to monitor retinol levels.

Finally, since retinol is not endogenously produced by porpoises but is absorbed from the diet, food quality may have a strong effect on resulting tissue levels. The harbour porpoises analysed here were from 3 different locations and it would not be surprising if this had resulted in variations in diet and, therefore, in retinol concentration. This needs to be taken into account not only when individuals from different regions are analysed, but also when differences in diet composition between different components of a given, local population are suspected. For example, variation in diet associated with age, sex or reproductive condition has been reported for many cetaceans (Seaman et al. 1982, Bernard \& Hohn 1989, Clarke et al. 1993), including the harbour porpoise (Recchia \& Read 1989, Smith \& Read 1992).

The depressor effect of PCBs and other organochlorine compounds on retinol levels in mammals, leading to vitamin $A$ depletions, has been reported for several pinniped species, both experimentally (Brouwer et al. 1989, Swart et al. 1994) and in the wild (Jenssen et al. 1995). Retinol has a potential for use as a biomarker to evaluate overall physiological impact for at least 2 reasons. First, reduction in retinol tissue levels appears to be elicited even with moderate exposure to organochlorines (Håkansson et al. 1992, Jenssen et al. 1995). Second, normal retinol levels are restored when exposure to pollutants disappears or significantly decreases (Brouwer et al. 1989). Therefore, retinol is foreseen as a likely sensitive indicator of overall organochlorine physiological impact. However, proper assessment of retinol tissue concentration variations can only be achieved with a thorough understanding of the patterns of variability in natural conditions. Further research is needed in order to establish with greater precision such patterns in other populations and species of cetaceans.

Acknowledgements. Retinol analyses were carried out in the 'Serveis Científico Tècnics' of the University of Barcelona. The authors wish to acknowledge Inuit hunters who provided the harbour porpoises for the sampling and the assistants who contributed to the field work and data collection. The collection of harbour porpoise samples was funded by the Inuit $\mathrm{Cir}$ cumpolar Conference and the Greenland Institute of Natural Resources and the laboratory analyses by CICYT project AMB 94-0399.

\section{LITERATURE CITED}

Aguilar A, Borrell A (1990) Patterns of lipid content and stratification in the blubber of fin whales (Balaenoptera physalus). J Mammal 71(4):544-554
Aguilar A, Borrell A (1994) Assessment of organochlorine pollutants in cetaceans by means of skin and hypodermic biopsies. In: Fossi MC, Leoncio C (eds) Nondestructive biomarkers in vertebrates. Lewis Publishers, Boca Raton, FL, p 245-267

Aguilar A, Borrell A (1995) Pollution and harbour porpoises in the eastern North Atlantic: a review. Rep Int Whal Comm (Spec Issue) 16:231-242

Aguilar A, Borrell A, Pastor T (1999) Factors affecting variability of persistent pollutant levels in cetaceans. J Cetacean Res Manage (Spec Issue) 1 in press

Bernard HJ, Hohn AA (1989) Differences in feeding habits between pregnant and lactating spotted dolphins (Stenella attenuata). J Mammal 70:211-215

Blaner WS, Obundike JC, Kurlandsky SB (1994) Lipoprotein lipase hydrolysis of retinyl ester. J Biol Chem 269: 16559-16565

Blomhoff R, Berg T, Norum KR (1988) Distribution of retinol in rat liver cells: effect of age, sex and nutritional status. $\mathrm{Br}$ J Nutr 60(2):233-239

Blomhoff R, Green MH, Green JB, Berg T, Norum KR (1991) Vitamin A metabolism: new perspectives on absorption, transport, and storage. Physiol Rev 71(4):951-990

Braekkan OR (1948) Vitamins in whale liver. Sci Res Mar Biol Res 32:1-25

Brouwer A, Reijnders PJH, Koeman JH (1989) Polychlorinated biphenyl (PCB)-contaminated fish induces vitamin $A$ and thyroid hormone deficiency in the common seal (Phoca vitulina). Aquat Toxicol 15:99-106

Bryden MM (1972) Growth and development of marine mammals. In: Harrison RJ (ed) Functional anatomy of marine mammals, Vol. 1. Academic Press, London, p 1-81

Clarke, MR, Martins HR, Pascoe P (1993) The diet of sperm whales (Physeter macrocephalus Linnaeus 1758) off the Azores. Phil Trans R Soc Lond B339:67-82

Geraci JR, St Aubin DJ, Smith TG (1979) Influence of age, condition, sampling time, and method on plasma chemical constituents in free-ranging ringed seals, Phoca hispida J Fish Res Board Can 36(10):1278-1282

Gregory ME, Kon SK, Rowland SJ, Thompson SY (1955) The composition of the milk of the blue whale. J Dairy Res 22 : $108-112$

Håkansson H, Manzoor E, Ahlborg UG (1992) Effects of technical PCB preparations and fractions thereof on vitamin $A$ levels in the mink (Mustela vison). Ambio 21(8):558-590

Ishikawa S, Omote Y. Soma Y (1948) Analytical distillation of vitamin $A$ in the whale liver oil. Sci Rep Whales Res Inst Tokyo 2:35-41

Ishikawa S, Omote Y, Okud H (1951) Substances related to vitamin $A$ in the whale liver oil. Sci Rep Whales Res Inst Tokyo 5:53-69

Jenssen BM, Skaare JU, Woldstad S, Nastad AT, Haugen O, Kloven B, Sormo EG (1995) Biomarkers in blood to assess effects of polychlorinated biphenyls in free-living grey seal pups. In: Blix AS, Walloe L, Ulltang O (eds) Whales, seals, fish and man. Elsevier, Amsterdam, p 607-615

Käkelä R, Hyvärinen $H$, Käkelä A (1997) Vitamins A-1 (retinol), A-2, (3,4 didehydroretinol) and $E$ (alpha-tocophherol) in the liver and blubber of lacustrine and marine ringed seals (Phoca hispida sp.). Comp Biochem Physiol B $116: 27-33$

Kaneko A(1948) Molecular distillation of fin whale liver oil. Sci Rep Whales Res Inst Tokyo 2:46-50

Klem A (1935) Studies on the biochemistry of whale oils. Hvalradets Skrifter 11:49-108

Krasinski SD, Cohn JS, Shaeter EJ, Russell RM (1990) Postprandial plasma retinyl ester response is greater in older 
subjects compared with younger subjects: evidence for delayed plasma clearance of intestinal lipoproteins. Clin Invest $85883-892$

Lockyer C (1995a) Investigation of aspects of the life history of the harbour porpoise Phocoena phocoena. in British waters. Rep Int Whal Comm (Spec Issue) 16:189-197

Lockyer C (1995b) A review of factors involved in zonation in odontocete teeth, and investigation of the likely impact of environmental factors and major life events on harbour porpoise tooth structure. Rep Int Whal Comm (Spec Issue) 16:511-529

Lockyer C (1995c) Aspects of the morphology, body fat condition and biology of the harbour porpoise, Phocoena phocoena, in British waters. Rep Int Whal Comm (Spec Issue) 16:199-209

Maiani G, Mobarhan S, Ceccanti M, Ranaldi L, Gettner S, Bowen $P$ (1989) Beta-carotene serum responses in younger and elderly females. Eur J Clin Nutr 43:749-761

Mori T, Saiki M (1950) Properties of fats and oils contained in various parts of a sperm whale body. Sci Rep Whales Res Inst Tokyo 3:79-84

Morse DC, Brouwer A (1995) Fetal, neonatal, and long-term alterations in hepatic retinoid levels following maternal polychlorinated biphenyl exposure in rats. Toxicol Appl Pharmacol 131:175-182

Murphy PG (1972) Sulphuric acid for the clean-up of animal tissues for analysis of acid stable hydrocarbon residues. JAOAC (J Assoc Off Anal Chem) 55:1360-1362

NRC (National Research Council) (1987) Committee on biological marquers. Environ Health Perspect 74:3-9

O'Shea TJ, Aguilar A (in press) Cetaceans and sirenians. In: Shore RF, Rattner BA (eds) Ecotoxicology of wild mammals. John Wiley and Sons Ltd, New York

O'Shea TJ, Brownell RL (1994) Organochlorine and metal contaminants in baleen whales: a review and evaluation of conservation implications. Sci Total Environ 154:179-200

Peakall D (1992) Animal biomarkers as pollutant indicators Ecotoxicological Series 1. Chapman \& Hall, London

Raica N, Scott J, Lowry L, Sauberlich HE (1972) Vitamin A concentration in human tissues collected from five areas in the United States. Am J Clin Nutr 25:291-296

Recchia CA, Read AJ (1989) Stomach contents of harbour porpoises, Phocoena phocoena (L.), from the Bay of Fundy Can J Zool 67:2140-2146

Rig M, Lydersen C, Knutsen LØ, Bjørge A, Smith TG, Øritsland NA (1993) Scaling of insulation in seals and whales. $\mathrm{J}$ Zool (Lond) 230:193-206

Editorial responsibility: Otto Kinne (Editor),

Oldendorf/Luhe, Germany
Rodahl K, Davies AW (1949) Vitamin A in seals. Biochemistry 45:408-412

Rosas FCW, Lehti KK (1996) Nutritional and mercury content of milk of the Amazon river dolphin, Inia geoffrensis. Comp Biochem Physiol A 115(2):117-119

Schmidt-Nielsen S, Flood A, Stene J (1934) Uber Grösse und Vitamingehalt der Leber verschiedener Tiere. Kgl Norske Vidensk Selsk Forhandlinger 7:81

Schweigert FJ, Buchholz Y (1995) Vitamin A metabolism in carnivores with special reference to fur bearing animals. Scientifur 19(4):305-307

Schweigert FJ, Stobo WT, Zucker H (1987) Vitamin A Status in the grey seal (Halichoerus grypus) on Sable Island. Int $\mathrm{J}$ Vit Nutr Res 57:239-45

Seaman GA, Lowry LF Frost, KJ (1982) Foods of belukha whales (Delphinapterus leucas) in western Alaska. Cetology $44: 1-19$

Slijper EJ (1958) Organ weights and symmetry problems in porpoises and seals. Arch Neerl Zool (Suppl) 13:97-113

Smith RJ, Read AJ (1992) Consumption of euphausiids by harbour porpoise (Phocoena phocoena) calves in the Bay of Fundy. Can J Zool 70:1629-1632

Southcott RV, Chesterfield NJ, Warneke RM (1974) The vitamin A content of the liver of the Australian fur seal, Arctocephalus pusillus doriferus. Aust Wildl Res 1:145-149

Spear PA, Bilodeau AY, Branchaud A (1992) Retinoids: from metabolism to environmental monitoring. Chemosphere 25(11): 1733-1738

Swart R de L, Ross PS, Vedder LJ, Timmerman HH, Heisterkamp S, Loveren H van, Vos JG, Reijnders PJH, Osterhaus DME (1994) Impairment of immune function in harbor seals (Phoca vitulina) feeding on fish from polluted waters. Ambio 23(2):155-159

Tawara T, Fukazawa R (1950a) Studies on kitol. I. Preparation of kitol from whale liver oil. Sci Rep Whales Res Inst Tokyo 3:85-88

Tawara T, Fukazawa R (1950b) Studies on kitol. II. Influence of kitol fraction on the determination of the international unit of vitamin A. Sci Rep Whales Res Inst Tokyo 3:89-95

Wetlesen, CU (1938) Whale Liver. Norsk Hvalfangst-Tidende $27: 262-264$

Wolf G (1994) Uptake of retinoids by adipose tissue. Nutr Rev 52(10):356-358

Zaman Z, Fielden P, Frost PG (1993) Simultaneous determination of vitamins $A$ and $E$ and carotenoids in plasma by reversed-phase HPLC in elderly and younger subjects. Clin Chem 39(10):2229-2234

Submitted: September 23, 1998, Accepted: March 16, 1999 Proofs received from author(s): July 28, 1999 